\title{
The Use of Decorative Styles of Woven Songket as a Source of Learning in the Course Textile Design and Decoration
}

\author{
I Dewa Ayu Made Budhyani ${ }^{1, *}$ \\ 1Department of Primary School Teacher Education, 81111, Singaraja, Indonesia
}

\begin{abstract}
The use of learning sources in the learning process greatly contributes to the achievement of its goal. The use of learning sources greatly affects the teaching and learning process. It is necessary to use different learning sources when creating a textile design in order to produce a quality product. The decorative style of woven songket can be used as one of the learning sources. The different decorative types of the woven songket contain aesthetic values. The decorative type of woven songket is a product of the crafter's feeling, creativity, and intention inspired by the environment. The natural objects such as plants, animals, human beings, and geometric elements are stylized into the decorative forms. The decorative style used on the woven songket can be used as the learning source in order to create the decorative style in the course Textile Design and Decoration. There are several aesthetic elements which inspire where the decorative style is placed; they are composition, rhythm, balance, the harmonious layout of the decorative style, and the variation of the decorative style on the textile design. In general, the composition of the placement of the main object of the decorative style is more dominant on the piece of fabric. Rhythm and how the decorative style is composed are shown through the composition of the decorative motive forms such as how big and small they are, how high and low they are and how long and short they are. The ways in which the decorative motives and colors are entirely shown contribute to the harmony and placement of decorative style. The symmetric balance is used to create balance and avoid the impression of being biased. The placement of what the motives contain and how they are composed are used to determine the variation of the decorative style used. The placement of objects and the marginal decoration of the fabric also determine the variation used.
\end{abstract}

\section{Introduction}

Indonesia has different types of people's industries, one of which is the woven songket industry. It is a cultural heritage which has been developing from generation to generation. The most conspicuous thing in the woven songket is the form of its decorative style. The balinese people are well known for their creativity in developing different art industrial

* Corresponding author: ayubudhyani@yahoo.com 
works. They can be found in different villages and towns with their different art industries. Many develop bamboo handicraft, weaving handicraft, rattan handicraft, wood handicraft, and many others develop other handicrafts with their respective specialty (ardika, 1996: 6).

The decorative style is a composition of lines, forms, colors and figures which are created to contain the values of beauty based on the development of imagination (hery suhersono, 2004: 5). The decorative style is the form of decorative background which is usually used as the repeated pattern of craft works. The decorative style reflects the beauty and aesthetic values causing the art works to be highly interesting and have quality.

The decorative style is based on the human knowledge of the environment which can inspire the creation of the diverse patterns of decoration. The natural objects which are translated into the forms of decorative style are plants, animals, human beings, natural elements, religious values. They are transformed into harmonious beauties (gelebet, 1982: 331). Such objects are transformed in such a way that different decorative styles can be created.

The decorative style on the songket woven fabric functions to decorate space which cannot be implicitly separated from the aspects of beauty. As an illustration the decorative style is used to enhance the beauty of a piece of fabric, causing it to look better and more interesting. As a consequence, it is materially and spiritually appreciated (gustmi sp. 1980). The forms of decoration, how they are colored, the way of making and placing them have particular meaning and intention. Decorations are formed in the form of patterns which allow them to be placed in several particular spaces of the elements needing decorating. The cultural factor was the initial factor which had inspired the woven songket crafters to produce traditional and modern motives. As we know that the balinese people have been well known for their culture, customs and traditions. They are also well known for their fidelity to hinduism (koentjaraningrat, 1985).

The weaving technique, locally referred to as 'teknik pakan tambahan', is used to create the decorative style of the woven songket. The process of making it is that a pinch of lint thread is taken before the golden or silver thread is inserted (cut karmail wardani, 2005:177). The way of raising the lint thread is organized with what is referred to as 'lidilidi' (a type of palm leaf rib). The more lidis are used the more complicated and richer the decorative style will be.

The decorative style is made up of different types of motives used to decorate an area or object. One, two or more motives are used to decorate an area. Some motives are repeated and some others are stylized. The motives are placed and composed of the elements which can support the beauty of the woven songket. The elements include form and structure, harmony, composition, rhythm or motion, balance, and so forth.

The types and forms of the decorative style placed/applied to the fabric of the woven songket can be used as the learning source to inspire the development of the source of ideas needed to create the designs of new decorative style. The learning sources include all the sources within and outside someone which allow (ease) the learning process to take place (ahmad rohani, 1997: 102). The educator is not the only source of teaching and learning, although his/her responsibility, role, and function in the teaching and learning process are highly important. The learning sources can be acquired from the learning environment which functions to maximize the learning outcome. Aect describes that the learning sources include: massage, human being, material, tool, technique, and environment (ahmad rohani, 1997: 108). Based on what was described on the decorative style above, the problem of the study can be formulated in the form of a question, namely how the decorative style of the woven songket can be used as a learning source viewed from its composition, rhythm, balance, the harmonious layout, and its varieties on the textile design and decoration. 


\section{Method}

This present study is a qualitative one in which the aesthetic approach was used. The object of the study is the decorative style of the woven songket as a learning source viewed from its composition, rhythm, balance and harmony. The data were obtained from the woven songket crafters. The data were collected through observation, interview, and documentation. All the data obtained from the field are related to composition, rhythm, balance, harmonious layout of the decorative style and the varieties of decorative style. The data were analyzed descriptively and qualitatively.

\section{Results and Discussion}

Based on the result of the study it can be stated that the elements used as the learning source in the placement of motives on the woven songket can be discussed as follows. The composition of the placement of the decorative style of the woven songket is adjusted to the type of the decorative style applied to the woven songket fabric. In general, not only one type of decorative style which is placed; however, the dominant decorative style is used as the main one, although there are several decorative styles used to complete the area of the woven songket. As an illustration, the composition of the placement of the decorative motive of hibiscus; there is space between one and another, causing empty space to be created in between. As a whole, all the decorative motives are arranged in such a way that they all have aesthetic values with respect to form, decorative motive and the type of color used to make the decorative motive on the woven songket fabric to vary. In addition to the composition of the main motive placed in the middle of the woven songket fabric, the supplementary motive is placed on the marginal part of the woven songket fabric. The placement of the decorative style is dependent on the goal and the size of the decorated area. The decorative style can be in the forms of the marginal ornamental style, cornering, regular, composition and repetition (Eko Purnomo, 2013). In general, not only one decorative style which is placed; however, the dominant decorative style is the main one, and the other decorative styles are used to complement the songket woven fabric. They can be in the geometric form, stylized plants, and animals.

The rhythm of the decorative style of the woven songket is repeatedly and regularly presented. The repeated composition of the decorative style is dependent on the type applied. What is meant by composition in this present study is that the same motives are repeatedly composed; however, they are not monotonously composed; as a result, there seems to be rhythm which can be presented by organizing the form of the decorative motive; it can be big, small, high, low, long, short, and by repeatedly composing different colors. The rhythmic motions can be made by repeating form, changing size, and moving the unbroken line (Diah Angendari, et al., 2014:9). The decorative style which is harmoniously placed can be seen from how the motives are composed or how the colors are presented as a whole on the woven sangket fabric. The presented threads used for making the woven fabric, its motives and colors as a whole can be seen from the harmonious aesthetic values. As the motives are placed harmoniously enough the colors composed on several motives with their complementary colors do not contradict one another. The balanced placement of the decorative style on the woven songket can be seen from the symmetric balance, which is the composition which is not seriously risky for the reason that it will not lead to the impression of being biased. The decorative motives similarly, repeatedly and entirely placed on the area of the fabric contribute to harmony. The decorative style on the woven songket fabric is placed in accordance with the decorative motive made. The reason is that each decorative motive has its own pattern. As an illustration, the pattern of the decorative motive tirtanadi is the same regardless of whoever 
makes it. It is made based on the source and is used as the decorative motive of the woven songket fabric. However, the complementary motive composed by the crafter cause the decorative motive to vary. The placement of the objects and the placement of the marginal decoration are also made to vary. When placing the decorative style on the woven songket, there are three components which need to be paid attention to; they are a figure as the main decoration, the supporting figures used to support the basic motive, and the complementary ones used to enrich beauty as a whole (Sila, 2013). Where the decorative style is placed is dependent on the goal and the area which is intended to be decorated.

The diversity of motives and the placement of the decorative style on the area of the woven songket fabric can be used as the learning source when making the pattern of the textile design and decoration. The knowledge of different types of natural and artificial materials can be used as the learning media (Sumanto et al, 2015). The sources of knowledge from the natural materials can be flora, fauna, geometric and figurative things.

\section{Conclusions and Suggestion}

The aspects of the decorative style of the woven songket which can be used as the learning sources can be concluded as follows: (1) the composition; in general, not only one decorative style is placed on the woven songket; however, the dominant decorative style is the main one; and the decorative style is entirely placed on the piece of the fabric. (2) Rhythm; the composition of the decorative style of the woven songket is regularly repeatedly presented. The repetition of the composition of the decorative motive depends on the type applied. In this present study, composition means the repeated composition of the same motive; however, the compositionis not monotonous; as a result, there seems to be rhythm. The rhythm which can be presented through the composition of the form of the decorative motive includes the size (big, small), height (high, low), length (long, short), and the repeated composition of different colors. (3) Harmony; the placement of the decorative style of the woven songket can be seen from how the decorative motive is composed and how colors are presented on the woven songket fabric as a whole. The motives are harmoniously placed enough; several motives are made with complementary colors and the colors used do not contradict one another. (4) Balance; the decorative style of the woven songket is placed in such a way that it is symmetrically balanced. The symmetric balance is the composition which is not seriously risky, as it will not give any impression of being biased. In general, the decorative style of the Jinengdalem woven songket is symmetric for the reason that the decorative style is repeatedly placed on the piece of fabric as a whole. (5) The decorative style of the woven songket is placed in accordance with the decorative motive made. The reason is that each decorative motive has a pattern. As an illustration, the decorative motive tirtanadi will be the same, whoever makes it. The pattern will be the same and follow the source as the decorative motive of the woven songket fabric of Jinengdalem. How the crafters compose the complementary motives vary. The placement of objects also varies and so does the placement of the marginal decoration.

\section{References}

1. Ahmad Rohani. Media Instruksional Edukatif. Jakarta:Rineka Cipta. (1997).

2. Angendari, Made Diah,dkk. Desain dan Dekorasi Tekstil. Yogyakarta:Graha Ilmu.(2014)

3. Ardika, I wayan. Dinamika kebudayaan Bali. Denpasar: Upada Sastra. (1996).

4. Eko Purnomo, dkk. "Seni Budaya". Jakarta: Kementrian Pendidikan dan Kebudayaan Republik Indonesia. (2013). 
5. Glebet, I Nyoman. Arsitektur Tradisional Daerah Bali.Departemen Pendidikan dan Kebudayaan. (1982).

6. Gustami, SP. Pembelajaran Sains Terkini Mendekatkan Siswa dengan Lingkungan Alamiah dan Sosial Budaya. Singaraja: Universitas Pendidikan Ganesha. (2009).

7. Koentjaraningrat. Kebudayaan Jawa. Jakarta : Balai Pustaka Nasution, S. 1988. Metode Penelitian Naturalistik Kualitatif. Bandung : Tersito. (1984)

8. Sanjaya, Wina. Ragam Hias. Denpasar : Departemen Pendidikan dan Kebudayaan.(2006)

9. Sila, I Nyoman dan I Dewa Ayu Made Budhyani. Kajian Estetika Ragam Hias Tenun Songket Jinangdalem Buleleng. Jurnal Ilmu Sosial dan Humaniora. Vol.2 No.1. 159165. (2013)

10. Soekarto dan Winardi. Menejemen Pemasaran. Jakarta : Erlangga. (1991).

11. Suhersono, Hery. Desain Bordir Motif Geometris. PT Gremedia Pustaka Utama.(2005).

12. Sujipta. Perubahan Sosial Masyarakat Dalam Hubungannya dengan masyarakat dan pariwisata Bali. Universitas Udanyana, Bali. (1989)

13. Sumanto, dkk. Kerajinan Tangan Di Blitar Sebagai Sumber Belajar Seni Budaya dan Prakarya (SBdP Sekolah Dasar). Jurnal Sekolah Dasar. Tahun 24 Nomor 2. 111-123. (2015).

14. Susanto, Mikke. Diksi Rupa. Yogyakarta : Penerbit Kanisius (Anggota IKAPI) (2002).

15. Wardani, Cut Karmail dan Ratna Pangabean. Tekstil. Lembaga Seni Nusantara. (2005).

16. Winardi. Menejemen Pemasaran. Jakarta : Erlangga. (1991).

17. Arif Syamsudin. "Antara Pelestarian dan Perlindungan Ekspresi Budaya Tradisional/Pengetahuan Tradisional dan Perlindungan Hak Kekayaan Intelektual". Media HKI. Volume V, No 4. (2008). 